\title{
7. METACOGNITIVE COMPETENCES AND IMPLICIT THEORIES OF INTELLIGENCE IN RELATION WITH SCHOOL ACHIEVEMENT
}

\author{
Adina-Petronela Vechiu ${ }^{254}$ \\ Nicoleta Laura Popa ${ }^{255}$
}

\begin{abstract}
This study aims to explore the relation between metacognitive competences, implicit theories of intelligence and school achievement among lower secondary students. The group of participants included 120 students from Iași County, with different socio-economic backgrounds. Participants completed two measures, Metacognitive Awareness Inventory (Schraw \& Dennison, 1994) and Implicit Theories of Intelligence Questionnaire (Dweck, 2000). School achievement was defined as annual average grades, and family socio-economic background was self-reported. Students from socio-economic disadvantaged families scored lower for metacognitive competence, and self-reported fixed mindset beliefs, in contrast with students with favourable socio-economic family background. Therewith, metacognitive competences and implicit theories of intelligence are significant predictors of school achievement.
\end{abstract}

Key words: metacognitive competences, implicit theories of intelligence, school achievement

\section{Introduction}

School achievement, as well as school failure and their determinants were constantly scrutinised in educational studies. In the last decades, school achievement is intensively explored within socio-cognitive frameworks, which emphasize new concepts as determinants. The present study focuses on two of the factors associated with school achievements and less addressed in Romanian empirical studies, namely metacognitive competences and implicit theories of intelligence, in conjunction with the effects of socio-economic status.

One of the issues faced by the Romanian educational system is a rather low level of school achievement reflected in both national and international assessments, and one of the explanatory factors is students' socio-economic background. In the second and the third volumes of $\operatorname{OECD}(2019,2020)$ report on PISA study conducted in 2018, growth mindset is depicted as an indicator of students' cognitive well-being, alongside socio-economic background, and shape a support frame for learning competences. The report also indicates that students with a disadvantaged socio-economic background set themselves less ambitious goals and have lower expectations for their school careers and achievements. The present study aims to add on empirical evidences suggesting the importance of metacognitive competences' awareness, and students' beliefs about their potential as predictors of school achievement, while taking into account the role of socioeconomic status (SES).

\footnotetext{
${ }^{254}$ Candidate Doctoral, „Alexandru Ioan Cuza” University from Iasi, Romania, e-mail: petronela.vechiu@uaic.ro.

255 Professor PhD. habil., „Alexandru Ioan Cuza” University from Iasi, Romania, e-mail: nicoleta.laura.popa@uaic.ro.
} 


\section{Metacognitive competences, SES and school achievement}

Although metacognitive competences are frequently addressed in both Romanian educational policy and public debates as key educational outcomes for graduates, they are largely neglected in educational practices. The concept of metacognition was introduced by John Flavell (1979), and defined as knowledge on cognitive phenomena and awareness on thinking process: what and how we think when faced with a task or situation, and why we think in a certain way. One of the most influential theoretical frameworks for metacognition is proposed by Schraw and Dennison (1994), and is fairly similar to the ones previously developed by Brown et al. (1983) and Jacobs and Paris (1987). A part of their contribution's popularity is due to association with a metacognition self-reported measure - the Metacognitive Awareness Inventory (MAI).

In contrast with previous definitions of metacognition, Schraw and Dennison (1994) orient metacognition towards learning environments, adding that it refers to the capacity to reflect on, understand and control learning. The theoretical frame develops on two dimensions: metacognitive knowledge covering declarative, procedural and conditional knowledge, and metacognitive regulation including processes such as planning, monitoring, evaluation and reflection on learning (Schraw, 1998). Later studies showed that metacognition is a powerful determinant of academic achievement, especially through self-monitoring learning and learning strategies (Cogliano, et. al.; 2020, Rahman, et. al. 2010; Schneider \& Lockl, 2002, 2008; Pintrich, 2002; Schraw, 1994).

However, there is still a certain gap in the educational literature on connections between metacognition and socio-economic status, as empirical data are scarce (Akin, 2016). A lot of empirical studies approached metacognition as cognitive self-regulation, either in the context of competence assessments in reading and mathematics (Rhodes, 2019; Thenmozhi, 2019; Daher et.al., 2018; Soto et. al. 2019; 2020; Young \& Worrell, 2018), or in promoting educational practices which may improve metacognition (Tanner, 2012; Keus \& Haave, 2020, Branigan \& Donaldson, 2020; Padmanabha, 2020).

\section{Implicit theories of intelligence, SES and school achievement}

The present study is based on the the motivational perspective about implicit theories of intelligence developed by Carol Dweck and Ellen Leggett (1983; 1988), which captured educationalists' attention due to the centrality of the goals connected either with learning or performance. Goals become motivational impulses that lead to a core of assumptions about the malleability of personal attributes (Dweck et al., 1995, Yeager \& Dweck, 2012). In other words, the model reflects on fundamental beliefs about flexibility of cognitive capacities and personality characteristics, beliefs which are eventually involved in interpreting the social world, regulate behaviours through goals' setting and adjustments after failure or through action strategies in diverse contexts (Dweck, 2006).

Incremental and entity theories have important consequences for individuals: thus, incremental theory covers beliefs and perceptions of intelligence as a flexible constructs, which may be continuously improved through effort and perseverance; 
on the other hand, entity theory refers to intelligence as a fixed construct, which cannot be changed or developed (Hong, 1999, Adamsone et al., 2020). Empirical studies already showed a moderate correlation between implicit theories of intelligence and school achievement, especially in adolescents: students who perceive intelligence a fixed trait tend to have lower school achievement, while students with incremental beliefs of intelligence obtain better school results (Cost \& Faria, 2018).

These results can be explained based on previous empirical studies which indicated that students with incremental beliefs on intelligence usually chose more challenging tasks and do no avoid failure situations (Blackwell et al., 2007, Dweck, 2006). By contrast, students with fixed beliefs on their cognitive abilities set up avoidance aims, and chose easy tasks which guarantee success and others' approval (Park \& Kim, 2015; Seo \& Lee, 2019). It is worthy to mention that individuals tend to adjust their mindsets to messages, experiences and specific contexts (e.g., parents' perceptions of students' school failure, received feedback, socio-economic status etc.), thus shifting between incremental and fixed beliefs (Haimovitz \& Dweck, 2016; Romero, et. al, 2014; Ashdown \& Bernard, 2012). Few studies approach specifically the relation between metacognitive competences, incremental theories of intelligence and school achievement; some of them (e.g., Oyserman \& Lewis, 2017; Destin et. all., 2019) showed that indicators as family income are powerful determinants of learning motivation, especially when socio-economic resources and parental support are limited.

\section{Aims and hypothesis}

The aim of the present study is to analyse the relation between awareness of metacognitive competences, implicit theories of intelligence and school achievement among lower secondary school students. We also intend to explore the effect of students' socio-economic background as additional predictor of school achievement. According with the research aim, we tested one main hypothesis: $\mathrm{H}_{1}$. Students' socio-economic background along with their awareness of metacognitive competences and implicit theories of intelligence (incremental and entity) significantly explain variations in school achievement.

\section{Method}

Participants. One hundred and twenty students in lower secondary school (65 girls; 55 boys) from the county of Iasi (Romania) voluntarily participated in the study. 63 students are members of single-parent families, while 57 are raised by both parents; 68 students live in rural areas, and 52 are part of urban families. Withal, 55 families have rather low monthly incomes, while 65 have an average level of monthly incomes; in 87 of the families, both parents completed upper secondary education, while in 33 cases both parents hold a higher education degree.

Measures. Awareness of metacognitive competences was measures with Metacognitive Awareness Inventory (MAI; Schraw \& Dennison, 1994) which includes 52 five points Likert-scale items. Individual scores are computed by 
summing responses for each item. In the present study, the level of internal homogeneity was satisfactory, with a computed Cronbach's alpha of 0.97 . The Mindset Questionnaire (Dweck, 2000) was used for investigating implicit theories of intelligence; it includes 20 items with 4 points Likert scale items, and allows the assessment of incremental and fixed mentalities. For the scale of incremental mentality computed Cronbach's alpha is 0.84 , and for the scale of fixed mentality the value of the same coefficient is 0.84 .

Procedure. Measures were self-administered on-line, together with a questionnaire covering socio-demographic variables (gender, rural or urban background, family socio-economic status reported as monthly level of average incomes). School achievement was also self-reported by participants, as the average school grade in the previous semester. Socio-economic background was measured on a nominal scale, indicating a low, respectively high self-perceived level, in connection with an average income indicated by the researchers.

\section{Results}

The relation between participants' socio-economic background and awareness of metacognitive competences, respectively implicit theories of intelligence and school achievement was explored with a set of Independent Samples T-Tests. Results suggest significant differences among lower secondary school students in terms of self-reported implicit theories of intelligence: students with a disadvantaged socio-economic background tend to score lower on the incremental mentality scale $\left[\mathrm{t}(118)=-3.895 ; \mathrm{p}=0.00 ; \quad \mathrm{M}_{\text {LowS }}=33.18 ; \mathrm{M}_{\mathrm{HighS}}=39.98\right]$, while students from families with higher incomes tend to score lower on fixed mentality scale $\left[\mathrm{t}(118)=-4.181 ; \mathrm{p}=0.00 ; \mathrm{M}_{\text {LowS }}=30.76 ; \mathrm{M}_{\text {HighS }}=37.89\right]$. Self-reported levels of metacognitive competences are also significantly influenced by students' selfperceived socio-economic status $\left[\mathrm{t}(118)=4.36 ; \mathrm{p}=0.00 ; \mathrm{M}_{\text {LowS }}=167 ; \mathrm{M}_{\text {HighS }}=\right.$ 204].

These results are in line with conclusions advanced by Costa \& Fraia (2018), based on a meta-analysis covering 46 studies (94 effects) with 412.022 students; socio-economic background is low to moderately associated with students' implicit theories of intelligence and their school achievement. The study also indicated that associations between implicit theories of intelligence and school achievement are significant for specific categories of students, such as students from disadvantaged families or affected by low parental support. According to previous studies, the socio-economic status may determine high levels of stress, anxiety and self-esteem, thus negatively influencing learning processes and leading to fixed, dysfunctional beliefs on improving intellectual abilities (e.g., Cedeño et al., 2016). On the other hand, students with high socio-economic status tend to report a better awareness of their metacognitive competences and a rather incremental mentality, given their additional chances to access early in their lives reasonable educational resources, read more and enrich their vocabulary, are exposed to stimulating life experiences such as extracurricular activities (e.g., Hackman et al., 2010; Dolean et al., 2019).

The exploration of the relation between awareness of metacognitive 
competences (1), implicit theories of intelligence (2) and school achievement (3) among participants revealed significant and positive correlations of the predictors with school achievement (see Table 1 bellow).

Table 1. Means, standard deviation and correlation matrix for continuous variables $(N=120)$

$\begin{array}{llllllll}\text { Correlation coefficients } & M & S D & 1 & 2 & 3 & 4\end{array}$

$$
\text { (Pearson) }
$$

1. Awareness of metacognitive

$\begin{array}{llllll}187.20 & 49.9 & 1 & .95^{*} & .94 * & .33^{*}\end{array}$
competences

2. Incremental theories of intelligence

3. Fixed theories of intelligence

4. School achievement

$\begin{array}{lllllll}36.86 & 10.83 & .95^{*} & 1 & .92 * & .34 *\end{array}$

$\begin{array}{llllll}34.62 & 10.03 & .94 * & .92 * & 1 & .34 * \\ 8.86 & .95 & .33 * & .34 * & .34 * & 1 \\ * p<0.01\end{array}$

Based on relations suggested in the literature and our preliminary analysis, a hierarchical multiple regression analysis was used to explore socio-economic background (dummy variable, included in model 1), incremental theories of intelligence (added in model 2), entity theories of intelligence (added in model 3) and awareness of metacognitive competences (included in model 4) as predictors of school achievement.

Table 2. Unstandardized and standardized regression coefficients and Model Summary

\begin{tabular}{|c|c|c|c|c|c|c|c|c|c|}
\hline \multicolumn{10}{|c|}{ Coeficients and Model Summary } \\
\hline \multirow{2}{*}{$\begin{array}{l}3 \\
0 \\
0 \\
0\end{array}$} & \multirow[t]{2}{*}{$\mathrm{B}$} & \multirow[t]{2}{*}{ SE } & \multirow[t]{2}{*}{$\beta$} & \multirow[t]{2}{*}{$\mathrm{R}$} & \multirow[t]{2}{*}{$\mathrm{R}^{2}$} & \multirow{2}{*}{$\begin{array}{c}\text { Adjusted } \\
\mathrm{R}^{2}\end{array}$} & \multirow[t]{2}{*}{$\mathrm{SE}$} & \multicolumn{2}{|c|}{ Change Statistics } \\
\hline & & & & & & & & $\mathrm{R}^{2}$ & $\mathrm{~F}$ \\
\hline 1 & ,631 & , 166 & ,331 &, $331^{\mathrm{a}}$ &, 110 & ,102 & ,90396 &, 110 & 14,522 \\
\hline \multirow[t]{2}{*}{2} & ,619 & , 168 & ,325 &, $334^{\mathrm{b}}$ &, 111 & ,096 & ,90694 & ,002 & 224 \\
\hline &,- 007 & 014 &,- 042 & & & & & & \\
\hline \multirow[t]{3}{*}{3} & ,268 & 170,0 & 140 &, $512^{\mathrm{c}}$ & 262 & 243 & ,83008 & 151 & 23,672 \\
\hline & 018 & 14,01 & , 115 & & & & & & \\
\hline & 072 & 5 & ,467 & & & & & & \\
\hline \multirow[t]{4}{*}{4} & ,268 & , 171,0 & ,141 &, $512^{\mathrm{d}}$ & ,262 & ,236 & ,83367 & ,000 & ,002 \\
\hline & ,018 & 16,02 & ,113 & & & & & & \\
\hline & 072 &, 003 & ,470 & & & & & & \\
\hline & ,000 & &,- 006 & & & & & & \\
\hline
\end{tabular}

Note: Model 1:socio-economic background

Model 2:socio-economic background, incremental midset

Model 3: socio-economic background, incremental midset, fixed mindset

Model 4: socio-economic background, incremental midset, awareness of metacognitive competences

The findings indicate that model 3 has the highest adjusted coefficient of determination (0.243), the increase compared to model $1 \Delta \mathrm{R} 2=0.102$ being significant $(\mathrm{p}<0.01)$ Thus, model 3 explains $24.3 \%$ of the variance of the variable school achievement by $14.1 \%$ more than model 1 this increase being statistically 
significant $(\mathrm{p}<0.01)$. Model 3 in the present study covers as predictors the socioeconomic background, growth/incremental mindset and fixed/entity mindset.

\section{Discussions and conclusions}

Although the reasearch hypothesis is partially confirmed, these results add to the body of empirical evidence regarding the relationships between school achievement and related explanatory variables selected for the study, based on the literature - socio-economic status, awareness of metacognitive skills and implicit theories of intelligence. As the results show, the fixed/entity mindset is a significant predictor of high performance, and this outcome is consistent with previous studies, suggesting that students with a fixed/entity mindset tend to become more competitive, they rather follow the grades that place them at the top of the rankings and are less interested in developing skills and competencies (Dupeyrat \& Mariné, 2005; Wang et al, 2018).

Other observational studies have shown that students with a fixed mindset avoid more difficult tasks and prefer to engage in activities that guarantee their success without making any efforts, and maintain a positive self-image in relation with others (Elliot et al., 1999; Ames, 1992; Dweck \& Leggett, 1988). Other factors that may explain this process may be parents' expectations, the style of family involvement in the child's education or the competitive climate in the classroom (Khajehpour \& Ghazvini, 2011).

Despite certain limits, the present study represents a first step in investigating moderating effects of several relevant variables (e.g., family support and involvement with school) in between targeted students' characteristics and their level of school achievement. At the same time, these results may have educational implications, as they draw attention to the importance of metacognitive competences, and incremental and growth mindset in determining a positive school path.

\section{References}

1. Adamsone, I., Gudakovska, N., \& Svence, G., (2020), Implicit theories of intelligence and academic achievement: Review of two studies in Latvia, „Problems of Psychology in the 21st Century”, 14(1), 7-17

2. Akin, E.,(2016), Examining the relation between metacognitive understanding of what is listened to and metacognitive awareness levels of secondary school students, „Educational Research and Reviews”, 11(7), 390-401

3. Ames, C., (1992), Achievement goals and the classroom motivational climate, in D. H. Schunk \& J. L. Meece (Eds.), „Student perceptions in the classroom”, 327-348, Hillsdale, NJ England: Lawrence Erlbaum Associates, Inc.

4. Ashdown, D. M., \& Bernard, M. E., (2012), Can explicit instruction in social and emotional learning skills benefit the social-emotional development, wellbeing, and academic achievement of young children?, „Early Childhood Education Journal", 39(6), 397-405 
5. Blackwell, L. S., Trzesniewski, K. H., \& Dweck, C. S., (2007), Implicit theories of intelligence predict achievement across an adolescent transition: A longitudinal study and an intervention, „Child Development”, 78(1), 246-263

6. Branigan, H. E., \& Donaldson, D. I., (2020), Teachers matter for metacognition: Facilitating metacognition in the primary school through teacher-pupil interactions, „Thinking Skills and Creativity”, 38, 100718

7. Brown, A.L., Bransford, J.D., Ferrara, R.A., \& Campione, J.C. (1983). Learning, remembering and understanding. In J.H. Flavell \& E.M. Markman (Eds.), P.H. Mussen (Series Ed.), „Handbook of child psychology 4th ed. Cognitive development", 3 (77-166), New York: John Wiley \& Sons

8. Cedeño, L.F., Martínez-Arias, R., \& Bueno, J.A., (2016), Implications of Socioeconomic Status on Academic Competence: A Perspective for Teachers, „International Education Studies”, 9, 257-267

9. Cogliano, M., Bernacki, M. L., \& Kardash, C. M., (2020), A metacognitive retrieval practice intervention to improve undergraduates' monitoring and control processes and use of performance feedback for classroom learning, „Journal of Educational Psychology". Advanced online publication, https://www.proquest.com/docview/2124443276, link accessed on January 2021 10. Costa, A., \& Faria, L., (2018), Implicit theories of intelligence and academic achievement: A meta-analytic review, „Frontiers in Psychology”, vol. 9, Article 829, https://www.frontiersin.org/articles/10.3389/fpsyg.2018.00829 /full, link accessed on January, 2021

11. Daher, W., Anabousy, A. \& Jabarin, R., (2018), Metacognition, positioning and emotions in mathematical activities, „International Journal of Research in Education and Science", 4(1), 292-303

12. Destin M, Hanselman P, Buontempo J, Tipton E, Yeager DS, (2019), Do Student Mindsets Differ by Socioeconomic Status and Explain Disparities in Academic Achievement in the United States?, „Advances in Developing Human Resources", 5 (3), 1-12

13. Dolean, D., Melby-Lervåg, M., Tincas, I., Damsa, C., \& Lervåg, A., (2019), Achievement gap: Socioeconomic status affects reading development beyond language and cognition in children facing poverty, „Learning and Instruction”, 63, 101218, https://www.sciencedirect.com/science/article/pii/ S0959475218308703, link accesed on December, 2020

14. Dupeyrat, C. \& Mariné, C., (2005), Implicit theories of intelligence, goal orientation, cognitive engagement, and achievement: A test of Dweck's model with returning to school adults, „Contemporary Educational Psychology”, Vol. 30 (1), 43-59

15. Dweck, C. S., \& Elliott, E. S., (1983), Achievement motivation. In P. H. Mussen \& E. M. Hetherington (eds.), „Handbook of chid psychology”,Vol. IV. „Social and personality development”, 643-691, New York: Wiley

16. Dweck, C. S., \& Leggett, E. L., (1988), A social-cognitive approach to motivation and personality, ,Psychological Review”, 95(2), 256-273

17. Dweck, C.S., (2006), „Mindset. The New Psychology of Succes”, New York: Random House 
18. Dweck, C.S., Chiu, C. \& Hong, Y, (1995), Implicit Theories: Elaboration and Extension of the Model, „Psychological Inquiry”, 6, 322-333

19. Elliott, R., Fischer, C.T. \& Rennie D.L, (1999), Evolving guidelines for publication of qualitative research studies in psychology and related fields, „British Journal of Clinical Psychology”, 38, 215-229

20. Flavell, J., (1979), Metacognition and Cognitive Monitoring: A New Area of Cognitive-Developmental Inquiry, ,American Psychologist”, 34, 906-911

21. Hackman, D., Farah, M. \& Meaney, M., (2010), Socioeconomic status and the brain: mechanistic insights from human and animal research., „Nature Reviws Neuroscience", 11, 651-659

22. Haimovitz, K., \& Dweck, C. S., (2016), What predicts children's fixed and growth intelligence mind-sets? Not their parents' views of intelligence but their parents' views of failure, „Psychological Science”, 27(6), 859-869

23. Hong, Y.-Y., Chiu, C.-Y., Dweck, C. S., Lin, D. M.-S., \& Wan, W., (1999), Implicit theories, attributions, and coping: A meaning system approach, „Journal of Personality and Social Psychology", 77(3), 588-599

24. Jacobs, J., \& Paris, S., (1987), Children's metacognition about reading. Issues in definition, measurement, and instruction. „Educational Psychologist”, 22, 255278

25. Keus, K., \& Haave, N. C., (2020), Using a learning philosophy assignment to capture students' metacognition and achievement goals, „The Canadian Journal for the Scholarship of Teaching and Learning", 11(1), https://doi.org/10.5206/cjsotl-rcacea.2020.1.815, link accesed on January, 2021

26. Khajehpour, M., \& Ghazvini, S. D., (2011), The role of parental involvement affect in children's academic performance, „Procedia - Social and Behavioral Sciences", 15, 1204-1208

27. OECD, (2019), PISA 2018 Results (Volume II): Where All Students Can Succeed, PISA, OECD Publishing, Paris

28. OECD, (2020), Students' self-efficacy and fear of failure, in PISA 2018 Results 3, What School Life Means for Students' Lives (40-42), OECD Publishing, Paris

29. Oyserman, D.\& Lewis, N.A., Jr., (2017), Seeing the Destination AND the Path: Using Identity-Based Motivation to Understand and Reduce Racial Disparities in Academic Achievement, „Social Issues and Policy Review”, vol. $11,159-194$

30. Padmanabha, C. H., (2020), Metacognition: Conceptual Framework, „Journal on Educational Psychology", 14(1), 1-11

31. Park, D., Kim S., (2015), Time to Move On? When Entity Theorists Perform Better Than Incremental Theorists, „Personality and Social Psychology Bulletin”, 41(5), 736-748

32. Pintrich, P., (2002), The Role of Metacognitive Knowledge in Learning, Teaching, and Assessing, „Theory Into Practice”, 4(4), 219-225

33. Rahman, F., Jumani, N.B., Chaudry, M.A., Chisti, S.U., \& Abbasi, F., (2010), Impact Of Metacognitive Awareness On Performance Of Students In Chemistry, „Contemporary Issues in Education Research”, vol. 3, 39-44 
34. Rhodes, M. G., (2019), Metacognition, „Teaching of Psychology”, 46(2), 168175

35. Romero, C., Master, A., Paunesku, D., Dweck, C. S., \& Gross, J. J., (2014), Academic and emotional functioning in middle school: The role of implicit theories, „Emotion”, 14(2), 227-234

36. Schneider, W., \& Lockl, K., (2002), The development of metacognitive knowledge in children and adolescents, in T. J. Perfect \& B. L. Schwartz (Eds.), „Applied metacognition”, 224-257, Cambridge, UK: Cambridge University Press

37. Schneider, W., \& Lockl, K., (2008), Procedural metacognition in children: Evidence for developmental trends. In J. Dunlosky \& B. Bjork (Eds.), „A handbook of memory and metacognition", 391-409, Mahwah, NY: Erlbaum

38. Schraw, G., \& Dennison, R. S., (1994), Assessing metacognitive awareness, „Contemporary Educational Psychology”, 19(4), 460-475

39. Schraw, G., (1998), Promoting general metacognitive awareness, „Instructional Science”, 26, 113-125

40. Seo, E., Lee, H. Y., Jamieson, J. P., Reis, H. T., Beevers, C. G., \& Yeager, D. S., (2019), Trait attributions and threat appraisals explain the relation between implicit theories of personality and internalizing symptoms during adolescence, „Development and Psychopathology”, 33(2), 1-11

41. Soto, C., Blume, A., Bernal, M. \& Castro, M., (2020), The Role of Metacognitive Cues on the Comprehension of Proficient and Poor Readers, „Journal of Research in Reading”, 43, 272-289

42. Soto, C., Blume, A.P., Jacovina, M., McNamara, D., Benson, N., Riffo, B., \& Kruk, R., (2019), Reading comprehension and metacognition: The importance of inferential skills, „Cogent Education”, 6, 1565067, https://www.tandf online.com/doi/full/10.1080/2331186X.2019.1565067, link accesed on January, 2021

43. Tanner K. D., (2012), Promoting student metacognition, „CBE life sciences education", 11(2), 113-120

44. Thenmozhi, C., (2019), Models of metacognition, „Shanlax International Journal of Education", 7(2), 1-4

45. Wang, Y., Wu, C.-H., Parker, S.K. \& Griffin, M.A., (2018), Developing goal orientations conducive to learning and performance: An intervention study, „Journal of Occupational Organizational Psychology”, 91, 875-895

46. Yeager, D. S. \& Dweck, C., S., (2012), Mindsets that promote resilience: When students believe that personal characteristics can be developed, „Educational Psychologist”, 47 (4), 302-314

47. Young, A. E., \& Worrell, F. C., (2018), Comparing metacognition assessments of mathematics, academically talented students, „Gifted Child Quarterly”, 62(3), 259-275. 